\title{
PENGERTIAN DAN PROSES ADMINISTRASI KURIKULUM
}

\author{
Melia Sri Devi1, hade afriansyah2 \\ 1Universitas Negeri Padang, Padang, Indonesia (meliasridevi@gmail.com) \\ 2Universitas Negeri Padang, Padang, Indonesia, (hadeafriansyah@fip.unp.ac.id) \\ berguna sebagai alat untuk
}

\section{A. Pengertian Kurikulum}

Kurikulum dapat diartikan secara sempit dan secara luas. Secara sempit kurikulum diartikan sejumlah mata pelajaran yang harus diikuti atau diambil siswauntuk dapat menamatkan pendidikannya, pada lembaga tertentu, sedangkan secara luas kurikulum diartikan dengan semua pengalaman belajar yang diberikan sekolah kepada siswa selama mengikuti pendidikan pada jenjang pendidikan tertentu. Usaha-usaha untuk memberikan pengalaman belajar kepada siswa dapat berlangsung di dalam kelas maupun di luar kelas baik yang dirancang secara tertulis maupun tidak, asal ditujukan untuk membentuk lulusan yang berkualitas.

Dalam Undang-undang Nomor 20 tahun 2003 dikemukakan bahwa kurikulum adalah seperangkat rencana dan peraturan maengenai isi dan bahan pelajaran serta cara yang digunakan sebagai pedoman dalam pelaksanaan proses belajar mengajar.

Kurikulum merupakan suetu komponen yang sangat prnting dan menentukan dalam penyelenggaraan pendidikan. kurikulum berfungsi sebai alat untuk pencapaian tujuan pendidikan, apabila tujuan pendidikan berubah maka maka secara otomatis kurikulum juga harus dirubah. Bagi anak kurikulum mengembangkan segenap potensi-potensi yang dimilikinya ke arah yang lebih baik di bawah bimbingan guru di sekolah. Bagi guru kurikulum berfungsi sebagai pedoman dan acuan dalam penyelenggaraan pembelajaran di sekolah.

Kualitas keluaran proses pendidikan antara lain ditentukan oleh kurikulum dan efektifitas pelaksanaannya.kurikulum itu harus sesuai dengan filsafat dan cita-cita bangsa, perkembangan siswa, perkembangan ilmu dan teknologi, serta kemajuan dan tuntutan masyarakat terhadap kualitas lulusan lembaga pendidikan itu.

Jadi dapat disimpulkan bahwa kurikulum adalah seperangkat bahan pengalaman belajar siswa dengan segala pedoman pelaksanaannya yang tersusun secara sistematik dan dipedomani oleh sekolah dalam kegiatan mendidik siswa.

\section{B. Proses Administrasi Kurikulum}

\section{Perencanaan}

Perencanaan kurikulum sebagian besar dilaksanakan dan ditentukan oleh Departemen Pendidikan Nasional ditingkat pusat. Ini berarti bahwa ditingkat daerah dan sekolah tidak ada perencanaan 
kurikulum. Perencanaan kurikulum yang dilakukan oleh Departemen Pendidikan Nasional ditingkat pusat meliputi hal-hal berikut:

a. Penyusunan, program dan pengembangan kurikulum yang terdiri atas:

1) Landasan, program dan pengembangan kurikulum,

2) Garis-garis besar program pengajaran, dan

3) Pedoman pelaksanaan kurikulum.

b. Penyusunan pedoman teknis pelaksanaan kurikulum seperti pedoman penyusunan kalender pendidikan, pembagian tugas guru, penyusunan jadwal pelajaran, penyusunan program pengajaran dan pedoman penyusunan persiapan pengajaran.

Perencanaan kurikulum yang akan digunakan di sekolah seperti kurikulum tingkat satuan pendidikan harus berlandaskan kepada Pancasila sebagai falsafah negara dan Undang-undang Dasar 1945 yang mengamanatkan untuk mencerdaskan kehidupan bangsa. Untuk merumuskan kurikulum hendaknya diperhatikan prinsip-prinsip umum yang berlaku dalam pengembangan dan perumusan kurikulum itu sendiri yaitu:
a. Prinsip relevansi,
b. Prinsip efektifitas,
c. Prinsip efisiensi,
d. Prinsip continuitas dan,
e. Prinsip fleksibelitas.

Di samping itu, perencanaan kurikulum yang dilakukan ditingkat daerah juga meliputi penyusunan rencana pelaksanaan kurikulum seperti penyusunan kelender pendidikan untuk setiap tahun ajaran pada masing-masing daerah. Penyusunan kalender pendidikan dimaksudkan agar terdapat pembakuan pelaksanaan kegiatan di sekolah, sehingga setiap kepala sekolah dapat mengadakan perencanaan dan pengaturan secara cermat terhadap kegiatan di sekolah yang dipimpinnya.

Kalender pendidikan antara lain berisikan:

a. Permulaan tahun ajaran,

b. Penerimaan siswa barudan persiapan tahun ajaran baru,

c. Kegiatan pada hari-hari pertama masuk sekolah,

d. Hari belajar efektif di sekolah,

e. Upacara-upacara sekolah,

f. Hari-hari libur sekolah baik libur umum, libur khusus maupun libur semester atau catur wulan,

g. Ulangan semester atau catur wulan, UNAS,

h. Pengisian, pembagian rapor dan kenaikan kelas dan

i. Kegiatan-kegiatan ekstra kurikuler.

Dalam melaksanakan kalender pendidikan wajib memperhatikan prinsi-prinsip operasional kegiatan sekolah antara lain:

a. Setiap kegiatan mempunyai fungsi 
peningkatan mutu, efektifitas dan efisiensi pendidikan.

b. Setiap kegiatan mempunyai kaitan fungsional dengan kegiatan lainnya yang relevan.

c. Dalam fungsinya untuk meningkatkan mutu pendidikan kegiatan kurikuler dan ekstra kurikuler merupakan satu keseluruhan yang integratif.

d. Penjadwalan kegiatan ekstra kurikuler menjamin kelancaran dan efektifitas pelaksanaan kegiatan ekstra kurikuler.

\section{Pelaksanaan}

Kegiatan-kegiatan yang dilakukan guru dalam pelaksanaan kurikulum di sekolah meliputi:

a. Penyusunan Program Pengajaran Semesteran/Caturwulan

Tujuan penyusunan program pengajaran semesteran atau caturwulan ini adalah untuk:

1) Menjabarkan bahan pelajaran yang akan disajikan guru dalam proses belajar mengajar.

2) Mengarahkan tugas yang harus ditempuh guru agar pengajaran dapat dilakukan secara bertahap dan tepat.

Fungsi program pengajaran semester atau caturwulan ini adalah:

1) Pedoman bagi guru dalam penyelenggaraan pembelajaran selama satu semesteran dan caturwulan

2) Bahan oleh kepala sekolah dan pengawas dalam melakukan pembinaan terhadap guru.

Langkah-langkah yang ditempuh dalam menyusun program pengajaran semester/caturwulan yaitu:

1) Mempelajari GBPP mata pelajaran yang dibina.

2) Mengelompokkan bahan pengajaran yang tercantum dalam GBPP menjadi beberapa satuan bahasan.

3) Menghitung banyaknya satuan bahasan yang terdapat selam satu semester/caturwulan.

4)Menghitung banyaknya minggu efektif sekolah (belajar) selam satu semeter/caturwulan dengan melihat kalender pendidikan sekolah yang bersangkutan.

5) Mengalokasikan waktu yang dibutuhkan untuk setiap satuan bahasan sesuai dengan hari efektif sekolah.

6) Mengatur pelaksanaan proses belajar mengajar sesuai dengan banyaknya minggu efektif sekolah yang tersedia berdasarkan kalender pendidikan.

b. Penyusunan persiapan mengajar yang akan digunakan dan dipedomani oleh guru dalam melaksanakan proses belajar mengajar di kelas.

c. Pelaksanaan Proses Belajar Mengajar

d. Kegiatan Kokurikuler dan Ekstra Kurikuler

\section{Pengawasan}

Pengawasan identik dengan kata controlling yang berarti pemeriksaan. 
Sedangkan dalam kamus Bahasa Indonesia pengawasan adalah penilikan dan penjagaan, jadi pengawasan berarti mempertahankan dan menjaga dengan baik. Menurut winardi, pengawasan adalah semua aktivitas yang dilaksankan oleh pihak manajer dalam upaya memastikan bahwa hasil aktual sesuai dengan hasil yang direncanakan.

Pengawasan adalah fungsi administratif bagi setiap administrator untuk memastikan bahwa apa yang dikerjakan sesuai dengan yang dikehendaki. Pengawasan itu meliputi pemeriksaan apakah semua berjalan sesuai dengan rencana yang dibuat, instruksi-instruksi yang dikeluarkan dan prinsip-prinsip yang ditetapkan.

Menurut Simbolon (2004:
Pengawasan bertujuan
pelaksanaan pekerjaan diperoleh
berasil
berdaya guna (efisien) dan berhasil guna
(efektif) sesuai dengan rencana yang telah
ditentukan sebelumnya. Fungsi dari
pengawasan, Simbolon (2004:
mengemukakan bahwa, fungsi dari
pengawasan yaitu:

a. Mempertebal rasa dan tanggung jawab terhadap pejabat yang diserahi tugas dan wewenang dalam pelaksanaan pekerjaan.

b. Mendidik para pejabat agar mereka melaksanakan pekerjaan sesuai dengan prosedur yang ditentukan.

c. Untuk mencegah terjadinya penyimpangan, penyelewengan, kelalaian dan kelemahan, agar tidak terjadi kerugian yang tidak diinginkan.

d. Untuk memperbaiki kesalahan dan penyelewengan, agar pelaksanaan pekerjaan tidak mengalami hambatan dan pemborosan-pemborosan.

\section{Evaluasi}

a. Evaluasi hasil belajar

Evaluasi hasil belajar merupakan suatu kegiatan uang dilakukan guna memberikan berbagai informasi secara berkesinambungan dan menyeluruh tentang proses dan hasil belajar yang telah dicapai siswa. Tujuan dan fungsi evaluasi hasil belajar adalah:

1) memberikan umpan balik kepada guru dan siswa dengan tujaun untuk memperbaiki cara belajar mengajar, mengadakan perbaikan dan pengayaan bagi siswa, serta menempatkan siswa pada situasi belajar mengajar yang tepat sesuai dengan kemampuan yang dimilikinya.

2) memberikan informasi kepada siswa tentang tingkat keberhasilannya dalam belajar dengan tujuan untuk memperbaiki, mendalami atau memperluas pelajaran.

3) menentukan nilai hasil belajar siswa yang dibutuhkan untuk pemberian laporan kepada orang tu, penentuan kenaikan kelas, dan kelulusan siswa.

b. Evaluasi program pengajaran

Evaluasi program pengajaran merupakan suatu rangkaian kegiatan yang dilakukan dengan sengaja untuk melihat tingkat keberhasilan program, serta faktor-faktor yang mendukung atau menghambat keberhasilan program tersebut.

\section{Peran Guru dalam Administrasi Kurikulum}

Menurut Sri Herlina dalam diktat 
Profesi keguruan (2011:52) bahwa di sekolah, guru berada dalam kegiatan administrasi sekolah.Sekolah melaksanakan kegiatannya untukmenghasilkan lulusan jumlah dan mutunya telah ditetapkan. Dalam lingkup administrasi sekolah inilah peran guru sangat penting. Dalam menetapkan kebijaksanaan dan melaksanakan proses perencanaan, pengkoordinasian, pengarahan, pengorganisasian, pembiayaan dan penilaian kegiatan kurikulum, kesiswaan, sarana dan prasarana, personalia sekolah, keuangandan hubungan sekolah dengan masyarakat.

Disitulahguru harus aktif memberikan sumbangan maupun tenaganya. Administrasi sekolah adalah pekerjaan yang sifatnya kolaboratif artinya pekerjaaan yang didasarkan ataskerjasama dan bukan bersifat individual. Oleh karena itu, semua personel sekolah termasuk guru harusterlibat.

Berikut akan diurai akan dan dijelaskan kegiatan administrasi pendidikan sekali gusperanan guru dalam administrasipendidikan.

\section{AdministrasiKurikulum.}

Menurut Prof. Soetjipto dan Drs. Raflis Kosasi,Msc dalam bukunya yang berjudulProfesikeguruan bahwa kurikulum merupakan seperangkat bahan pengalaman belajar siswa dengan segala pedoman pelaksanaanya yang tersusun secara sistematik dan dipedomani oleh sekolah dalam kegiatan mendidik siswanya".

2. AdministrasiKesiswaan

Menurut Prof. Soetjiptodan Drs. RaflisKosasi,Mscdalambukunya yang berjudulProfesikeguruan (1999:165) bahwa administrasi kesiswaanmerupakan proses pengurusan segala hal yang berkaitan dengan siswa disuatu sekolah dimulai dari perencanaan penerimaan siswa, pembinaan selama siswa disekolah, sampai dengan siswa mernamatkan pendidikannya melalui penciptaan suasana yang kondusif terhadap berlangsungnya proses belajar mengajar yang efektif.

3. AdministrasiKesiswaan

Untuk menunjang pelaksanaan pendidikan diperlukan fasilitas pendukung yang sesui dengan tujuan kurikulum. Dalam mengelola fasilitas agar bermanfaat yang tinggi diperlukan aturan yang jelas serta pengetahuan dan keterampilan personel sekolah dalam administrasi sarana dan prasarana tersebut. 4. Administrasipersonal

Menurut Prof. Soetjiptodan Drs. Raflis Kosasi,Msc dalam bukunya yang berjudul Profesi keguruan (1999:175) personal pendidikan adalah golongan petugas yang membidangi kegiatan edukatif dan yang membidangi kegiatan non edukatif (ketatausahaan). Personel bidang edukatif adalah mereka yang bertanggung jawab dalam kegiatan belajar mengajar, yaitu guru dankonselor (BK).

\section{DAFTAR PUSTAKA}

Syahril. 2009. Profesi Kependidikan.Padang: UNP PRESS.

Soetjipto. 2009. Profesi Keguruan. Jakarta: Rineka Cipta. 